\title{
Associations of Polymorphisms in Anti- Müllerian Hormone (AMH Ile49Ser) and its Type II Receptor (AMHRII -482 A>G) on Reproductive Outcomes and Polycystic Ovary Syndrome: a Systematic Review and Meta-Analysis
}

\author{
Noel Pabalan ${ }^{a}$ Erik Montagnab ${ }^{b}$ Eloisa Singian ${ }^{c}$ Lani Tabangay $^{d}$ Hamdi Jarjanazi $^{e}$
}

Caio Parente Barbosa ${ }^{f}$ Bianca Bianco ${ }^{f}$

\begin{abstract}
${ }^{a}$ Center for Research and Development, Angeles University Foundation, Angeles City, Philippines; 'Laboratory of Research in Health Sciences Teaching, Faculdade de Medicina do ABC, Santo André, Brazil; 'College of Allied Medical Professions, Angeles University Foundation, Angeles City, Philippines; dDepartment of Biological Sciences, Angeles University Foundation, Angeles City, Philippines, eEnvironmental Monitoring and Reporting Branch, Ontario Ministry of the Environment, Toronto, ON, Canada, ${ }^{f} H u m a n$ Reproduction and Genetics Center, Department of Collective Health - Faculdade de Medicina do ABC, Santo André/SP, Brazil
\end{abstract}

\section{Key Words}

Anti-Müllerian hormone - Anti-Müllerian hormone type II receptor - AMH - AMHRII polymorphisms • Reproductive outcomes $\bullet$ Polycystic ovary syndrome $\bullet$ Meta-analysis

\begin{abstract}
Background/Aims: Reported associations of reproductive outcomes (RO) and polycystic ovary syndrome (PCOS) with genotypes of the Ile49Ser and $-482 \mathrm{~A}>\mathrm{G}$ polymorphisms in the Anti-Müllerian hormone $(A M H)$ gene and its type II receptor $(A M H R I I)$, respectively, have conflicting results. Methods: PubMed, Google Scholar and Science Direct databases were searched for studies that investigated Ile49Ser and -482A>G in RO and PCOS. Using the metaanalytic approach, we estimated risk (odds ratio [OR] with 95\% confidence intervals) using standard genetic models. Results: All calculated summary effects were non-significant. Overall associations of Ile49Ser and -482A $>\mathrm{G}$ with RO were absent (OR 0.95-0.99, $\mathrm{P}=0.76-0.96)$ but implied increased risk in PCOS (OR 1.07-1.17, P $=0.49-0.55)$. Where heterogeneity of the pooled ORs were present, its sources were explored using the Galbraith plot. Detection and omission of the outlying studies in both polymorphisms not only erased heterogeneity of the recalculated pooled outcomes but also changed direction of association, where null effects turned to increased risk (Ile49Ser in RO) and increased risk became reduced risk (-482A $>\mathrm{G}$ in PCOS). Implications of the Ile49Ser and $-482 A>G$, effects pointed to protection for Caucasians
\end{abstract}

N. Pabalan and E. Montagna have the same importance in the manuscript. 
(OR 0.64-0.89, $\mathrm{P}=0.36-0.73$ ) in $\mathrm{RO}$ and increased risk in PCOS (OR 1.19-1.45, $\mathrm{P}=0.28-0.65)$. Asian effects in RO and PCOS were variable (OR 0.97-1.24, $P=0.58-0.91)$. Conclusions: In summary, we found no evidence of significant associations of Ile49Ser and $-482 \mathrm{~A}>\mathrm{G}$ with RO and PCOS, although contrasting Ile49Ser effects were implied among Caucasians between RO (up to $0.36 \%$ reduced risk) and PCOS (up to 1.5 -fold increased risk).

\section{Introduction}

Reproductive outcomes (RO) in women encompass a range of gynecological issues which include ovarian insufficiency and failure as well as infertility. Infertility which could be attributed to precursor conditions such as polycystic ovary syndrome (PCOS) involves failure to achieve pregnancy after a year of unprotected intercourse [1]. RO has become a global health issue warranting couples to seek assisted reproductive technology methods [2]. Success of these methods depends on variability of patient characteristics, much of which is attributed to genetic factors that regulate female reproductive function. Single nucleotide polymorphisms (SNPs) in coding regions in the signaling pathways of the ovary could play an important role in RO, as they are responsible for synthesis of hormone receptors, metabolic enzymes or transport molecules.

The Anti-Müllerian hormone (AMH) aka Müllerian inhibiting substance is homodimeric and a member of the transforming growth factor-beta (TGF- $\beta$ ) superfamily [3]. AMH in the female is produced exclusively by ovarian granulosa cells of pre-antral and small antral follicles [4]. Its concentration declines with age and become undetectable after menopause [5]. The number of antral follicles are strongly correlated with the size of primordial follicle pool [6] which indicate status of ovarian function and reserve as shown by serum AMH levels [7]. AMH is involved in the regulation of follicular growth [8] and continues to be expressed in the growing follicles until they have reached the appropriate size and differentiation state [9]. AMH with its serum has been shown to be a good indicator of a patient's follicular response to controlled ovarian stimulation with gonadotropins [7]. A meta-analysis has reported $\mathrm{AMH}$ to be a good predictor of ovarian response [10].

The gene for $A M H$ is located on the small arm of chromosome 19 and consists of 5 exons $[11,12] . A M H$ is produced as a pro-hormone, which after secretion undergoes cleavage to generate a transforming growth factor-C-terminal fragment [13]. AMH exerts its biological effects through the $A M H$ type II receptor (AMHRII), which in turn activates $A M H$ type I receptor (AMHRI) and creates a downstream signaling pathway. The human gene for AMHRII is located on chromosome 12, consists of 11 exons and is expressed in granulosa and theca cells [14]. Recent studies in normo-ovulatory women have demonstrated an association of the polymorphisms of $A M H$ and its receptor (AMHRII) with estradiol levels during the early follicular phase of the menstrual cycle [15]. Therefore, genetic variants in the $A M H$ and AMHRII genes may influence hormone function in folliculogenesis causing infertility. Two polymorphisms in the $A M H$ gene and $A M H R I I$ are found at the Ile49Ser (rs10407022) and $-482 A>G$ (rs2002555) restriction sites, respectively [3]. Genetic studies have shown that these variants are associated with reproductive status of women which include infertility [16] and in the $A M H$ signaling pathway, play a role in usage of the primordial follicle pool, and also affect follicle counts as well as folliculogenesis [17]. Carriers of the $A M H 49$ Ser and $-482 \mathrm{G}$ alleles have higher follicular phase estradiol levels compared to non-carriers $[15,18]$. Also, carriers of the AMH 49Ser allele in PCOS, women were less likely to exhibit polycystic ovaries and low androgen levels (hyperandrogenism) [19-21], suggesting a contribution of $A M H$ polymorphism to the severity of PCOS. Considering these roles of $A M H$ in regard to regulating ovarian function, it has been postulated that the genetic variants in the $A M H$ signaling pathway could lead to an impaired reproductive function of women. Given the variable outcomes in the human reproduction investigations of the $A M H$ and $A M H R I I$ variants, we performed a meta-analysis to evaluate the role of Ile49Ser and $-482 \mathrm{~A}>\mathrm{G}$ in RO and PCOS. 


\section{Cellular Physiology Cell Physiol Biochem 2016;39:2249-2261 and Biochemistry \begin{tabular}{l|l} 
DOI: 10.1159/000447918 & (c) 2016 The Author(s). Published by S. Karger AG, Basel \\
www.karger.com/cpb
\end{tabular} \\ Pabalan et al.: AMH and AMHRII Genes, Reproductive Outcomes and Polycystic Ovary Syndrome}

\section{Materials and Methods}

Selection of studies

Using the terms "AMH", "Anti-Müllerian hormone", "polymorphism", "reproductive outcomes" and "polycystic ovary syndrome", we searched MEDLINE using PubMed, Science Direct and Google Scholar for association studies as of May 31, 2016 without language restrictions. References cited in the retrieved articles were also screened manually to identify additional eligible studies. Inclusion criteria included: (1) case-control study design evaluating the association between $A M H$ and AMHRII polymorphisms and RO, as well as PCOS, (2) sufficient genotype frequency data presented to calculate the odds ratios (ORs) and 95\% confidence intervals (CI).

\section{Data extraction}

Two investigators independently extracted data and reached consensus on all the items. The following information was obtained from each publication: first author's name, published year, country of origin, dominant ancestry of the study populations, study design, context of the study, type of ovarian response, use of the Hardy-Weinberg Equilibrium (HWE), AMH and AMHRII polymorphism studied, sample source, genotyping approach, matching information and genotype data. We extracted data that pertained to our investigation of RO and PCOS. We also calculated frequencies of the variant allele, deviations of the controls from HWE. Where studies reported the mean and 95\% CI, SD was derived as follows: $\mathrm{SD}=\sqrt{N} \times($ upper limit - lower limit) $/ 3.92$.

\section{Quality assessment of the studies}

We used the Clark-Baudouin Score (CBS) to evaluate methodological quality of the included studies [22]. This scale emphasizes statistics (i.e. P values, power and corrections for multiplicity) and includes genotyping methods as well as HWE. These among others, were addressed in several of the included papers. Thus we felt this to be most appropriate in assessing the methodological quality of the included studies. For case-control studies, CBS scores range from 0 (worst) to 10 (best) where scoring is based on quality (low for $<5$ and high for $\geq 5$ ).

\section{Meta-analysis}

We investigated polymorphisms in AMH (Ile49Ser) and AMHRII $(-482 \mathrm{~A}>\mathrm{G})$ whose influence was estimated using the standard genetic models (homozygous, recessive, dominant and codominant). These associations were expressed as OR, 95\% CI. Raw data for genotype frequencies, without adjustment, were used for calculating study-specific estimates of the OR. Significance of the pooled estimates was determined by the Z-test. Pooled estimates were obtained using either the fixed [23] (in the absence of heterogeneity) or random [24] (in its presence) effects models. Heterogeneity between studies was estimated using the $\chi^{2}$-based Q test [25]. Recognizing the low power of this test [26], significance threshold was set at $P=0.10$. We also quantified heterogeneity with the $I^{2}$ statistic which measures the degree of inconsistency among studies [27]. Significance was set at a P-value of $\leq 0.05$ throughout except in heterogeneity estimation. Pooled estimates were subjected to sensitivity analysis which involved omitting one study at a time and recalculating the pooled estimates, to test for robustness of the summary effect. Subgroup analysis based on ethnicity was performed on those comprising of three or more studies. Data were analyzed using Review Manager 5.3 (Copenhagen: Nordic Cochrane Centre, Cochrane Collaboration, 2014) and SigmaStat 2.3 (Systat Software, San Jose, CA). All comparisons in our meta-analysis had $<10$ studies, and because of the low sensitivity of the qualitative and quantitative tests [28], we did not investigate publication bias.

\section{Results}

\section{Included studies}

Figure 1 outlines our study selection process in a flowchart following PRISMA (Preferred Reporting Items for Systematic Reviews and Meta-Analyses) guidelines [29]. We identified a total of 116 citations during the initial search, from which 17 were omitted following a review of titles and abstracts. We retrieved the remaining 99 abstracts which after review, 73 
articles were excluded for not conforming to our inclusion criteria. Full-texts of the remaining 26 were obtained and read including the reference lists. From the 26, 10 were excluded for being duplicates or with absence of genotypic data. The remaining 16 articles were included in the meta-analysis. The epidemiological features and clinical characteristics these studies are outlined in Table 1 and 2. Nine and six examined RO [16, 30-37] and PCOS [19, 38-42], respectively, and one study examined both [43]. Publication years of the included studies ranged from 2008 to 2016. Eight studies each were Asian [33, 35-37, 40-43] and Caucasian $[16,19,30-32,34,38,39]$. In terms of study context for Ile49Ser, five focused on infertility or ovarian insufficiency $[16,33,36,37,43]$ and three addressed stimulation issues [30, 32, 35]. One was about assisted reproductive technology [31] and another addressed follicle recruitment [34]. All 16 articles addressed HWE and used blood as tissue source, but none of them explicitly mention about controls being matched to cases. For $-482 \mathrm{~A}>\mathrm{G}$, the studies addressed relationships between genes [39, 42], hormone levels [19, 38, 41] and PCOS. One PCOS study engaged in haplotype analysis [40]. Based on the CBS scores, methodological quality of the included papers was high (mean and standard deviation of $6.40 \pm 0.84$ and 5.57 \pm 1.40 for RO and PCOS, respectively). Tables 3 and 4 summarize the sample sizes, genotype and minor allele frequencies as well as HWE values for both polymorphisms in RO and PCOS. Controls in two studies for PCOS deviated from HWE $[41,42]$. Where genotype frequency values are zero, we applied the Laplace correction by adding a pseudo-count of one to all values of the data set [44] prior to generating the forest plots.

\section{Meta-analysis}

Tables 5 and 6 show no evidence of significant associations in all comparisons. The Ile49Ser overall effects in RO were essentially null (OR 0.95-0.99, $\mathrm{P}=0.76-0.98$ ) but implied increased risk in PCOS (OR 1.07-1.16, $\mathrm{P}=0.51-0.55)$. Outlier analysis changed these overall effects to increased risk for RO (OR 1.15-1.18, $\mathrm{P}=0.17-0.47$ ) and reduced risk for PCOS (OR $0.90-0.93, \mathrm{P}=0.30-0.69$ ). Figures 2 to 4 show effects of outlier treatment in the dominant model of Ile49Ser on direction of association. Figure 2 shows a pooled OR of <1.00 (OR 0.95). Figure 3 identifies two outlier studies below the -2 confidence limit $[16,43]$. Figure 4 shows the forest plot without the outliers that resulted in a changed pooled OR of $>1$ (OR 1.17). The $-482 \mathrm{~A}>\mathrm{G}$ overall effects yielded both an implied increased risk in RO (OR 1.02-1.24, P = 0.280.82 ) and in PCOS (OR 1.05$1.31, \mathrm{P}=0.54-0.80)$. Asian Ile49Ser effects were variable for RO but implied increased risk in $-482 \mathrm{~A}>\mathrm{G}$ in PCOS (OR 1.14$1.16, \mathrm{P}=0.50-0.76)$. By contrast, Caucasian effects implied an Ile49Ser protection in R0 (OR 0.64-0.89, $\mathrm{P}=0.36-0.73$ ) but increased risk in PCOS (OR 1.19-1.45, $\mathrm{P}=0.28-0.51$ ). Like-

Fig. 1. Flowchart of literature search and study selection.

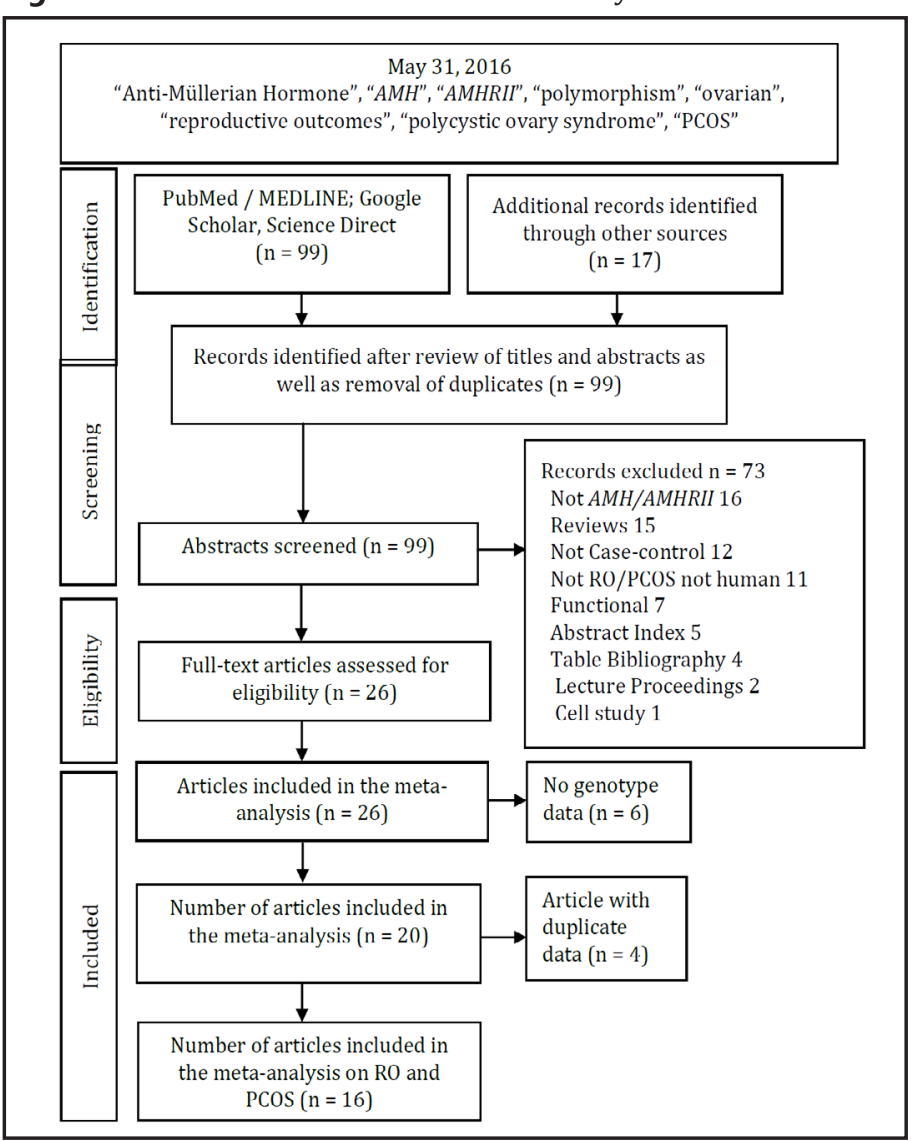


Pabalan et al.: AMH and AMHRII Genes, Reproductive Outcomes and Polycystic Ovary Syndrome

Table 1. Characteristics of the included articles that examined the association of AMH and AMHRII polymorphisms with RO in women. RO: Reproductive Outcomes; [R]: Reference; HWE: Hardy-Weinberg Equilibrium; RT-PCR: Reverse Transcriptase Polymerase Chain Reaction; CBS: Clark-Baudouin Score: assessment of methodological quality of the included studies

\begin{tabular}{|c|c|c|c|c|c|c|c|c|c|c|c|c|}
\hline & $\begin{array}{l}\text { First Author } \\
\text { (Year) }\end{array}$ & {$[\mathrm{R}]$} & Country & $\begin{array}{l}\text { Ethnic } \\
\text { group }\end{array}$ & Polymorphism & Context of study & Study design & $\begin{array}{l}\text { Used } \\
\text { HWE }\end{array}$ & $\begin{array}{l}\text { Tissue } \\
\text { Source }\end{array}$ & $\begin{array}{l}\text { Genotyping } \\
\text { platform }\end{array}$ & $\begin{array}{l}\text { Age of subjects: } \\
\text { mean } \pm S D \text { (range) }\end{array}$ & CBS \\
\hline 1 & $\begin{array}{l}\text { Hanevik } \\
2010\end{array}$ & {$[30]$} & Norway & Caucasian & $\begin{array}{l}\text { AMH: Ile49Ser } \\
\text { AMHRII: }-482 \mathrm{~A}>\mathrm{G}\end{array}$ & $\begin{array}{l}\text { Response to ovarian } \\
\text { stimulation }\end{array}$ & $\begin{array}{l}\text { Retrospective } \\
\text { case-control }\end{array}$ & Yes & blood & Taqman & $\begin{array}{l}\text { cases: } 32.6 \pm 5.33 y \text {; } \\
\text { controls: } 32.4 \pm 2 y\end{array}$ & 7 \\
\hline 2 & $\begin{array}{l}\text { Karagiorga } \\
2015\end{array}$ & {$[31]$} & Greece & Caucasian & $\begin{array}{l}\text { AMH: Ile49Ser } \\
\text { AMHRII: }-482 \mathrm{~A}>\mathrm{G}\end{array}$ & $\begin{array}{l}\text { Markers in assisted } \\
\text { reproduction technology }\end{array}$ & $\begin{array}{l}\text { Prospective } \\
\text { cross-sectional }\end{array}$ & Yes & blood & RT-PCR & $36 \pm 5 y$ & 6 \\
\hline 3 & $\begin{array}{l}\text { Lazaros } \\
2016\end{array}$ & {$[32]$} & Greece & Caucasian & AMHRII: $-482 \mathrm{~A}>\mathrm{G}$ & $\begin{array}{l}\text { Ovarian response to } \\
\text { gonadotropin stimulation }\end{array}$ & $\begin{array}{l}\text { Prospective } \\
\text { case-control }\end{array}$ & Yes & blood & PCR & $\begin{array}{l}33 \pm 4 \text { y for the } \\
\text { study population }\end{array}$ & 7 \\
\hline 4 & Rigon 2010 & [16] & Italy & Caucasian & $\begin{array}{l}\text { AMH: Ile49Ser } \\
\text { AMHRII: -482A>G }\end{array}$ & Unexplained infertility & $\begin{array}{l}\text { Observational } \\
\text { case-control }\end{array}$ & Yes & blood & PCR & $\begin{array}{l}\text { (28-38y) for both } \\
\text { groups }\end{array}$ & 6 \\
\hline 5 & $\begin{array}{l}\text { Voorhuis } \\
2011\end{array}$ & {$[34]$} & Netherlands & Caucasian & AMHRII: $-482 \mathrm{~A}>\mathrm{G}$ & Follicle recruitment & $\begin{array}{l}\text { Prospect-Epic } \\
\text { cohort }\end{array}$ & Yes & blood & PCR-SNP & $\begin{array}{l}63 \pm 3.4 y \text { for both } \\
\text { groups }\end{array}$ & 5 \\
\hline 6 & $\begin{array}{l}\text { Chunhua } \\
2012\end{array}$ & {$[43]$} & China & Asian & $\begin{array}{l}\text { AMH: Ile } 49 \mathrm{Ser} \\
\text { AMHRII: }-482 \mathrm{~A}>\mathrm{G}\end{array}$ & $\begin{array}{l}\text { Premature ovarian } \\
\text { failure }\end{array}$ & $\begin{array}{l}\text { Association } \\
\text { study }\end{array}$ & Yes & blood & PCR & $\begin{array}{l}\text { Cases: } 27 \pm 6 y \text {; } \\
\text { controls: } 28 \pm 5 y\end{array}$ & 6 \\
\hline 7 & Qin 2014 & {$[33]$} & China & Asian & AMH: lle49Ser & $\begin{array}{l}\text { Primary ovarian } \\
\text { insufficiency at } \\
\text { menopause }\end{array}$ & $\begin{array}{l}\text { Retrospective } \\
\text { case-control }\end{array}$ & Yes & blood & PCR & $\begin{array}{l}\text { cases: } 32 \pm 6 y \\
\text { controls: } 49 \pm 5 y\end{array}$ & 7 \\
\hline 8 & Wang 2015 & [35] & China & Asian & AMH: Ile49Ser & $\begin{array}{l}\text { Pathogenesis of early } \\
\text { ovarian hyperstimulation } \\
\text { syndrome }\end{array}$ & $\begin{array}{l}\text { Association } \\
\text { study }\end{array}$ & Yes & blood & PCR & $\begin{array}{l}\text { [20-35y] for both } \\
\text { groups }\end{array}$ & 6 \\
\hline 9 & Yoon 2013 & {$[36]$} & Korea & Asian & $\begin{array}{l}\text { AMH: lle49Ser } \\
\text { AMHRII: }-482 \mathrm{~A}>\mathrm{G}\end{array}$ & $\begin{array}{l}\text { Idiopathic primary } \\
\text { ovarian insufficiency }\end{array}$ & $\begin{array}{l}\text { Association } \\
\text { case-control }\end{array}$ & Yes & blood & Taqman & $\begin{array}{l}>45 y \text { post- } \\
\text { menopausal }\end{array}$ & 8 \\
\hline 10 & $\begin{array}{l}\text { Yoshida } \\
2014\end{array}$ & [37] & Japan & Asian & $\begin{array}{l}\text { AMH: Ile49Ser } \\
\text { AMHRII: }-482 \mathrm{~A}>\mathrm{G}\end{array}$ & Infertility & $\begin{array}{l}\text { Association } \\
\text { case-control }\end{array}$ & Yes & blood & Taqman & $\begin{array}{l}\text { Homozygous: } 38.7 \\
\pm 4.2 \mathrm{y} \text { Wild: } 38 \\
\pm 4.7 \mathrm{y}\end{array}$ & 6 \\
\hline
\end{tabular}

Table 2. Characteristics of the included articles that examined the association $A M H$ and AMHRII polymorphisms with PCOS. [R]: Reference; PCOS: Polycystic Ovary Syndrome; HWE: Hardy-Weinberg Equilibrium; NM: No Mention; MALDI-TOF: Matrix-Assisted Laser Desorption/ Ionization Time-of-Flight; CBS: PCR: Polymerase Chain Reaction; Clark-Baudouin Score: assessment of methodological quality of the included studies

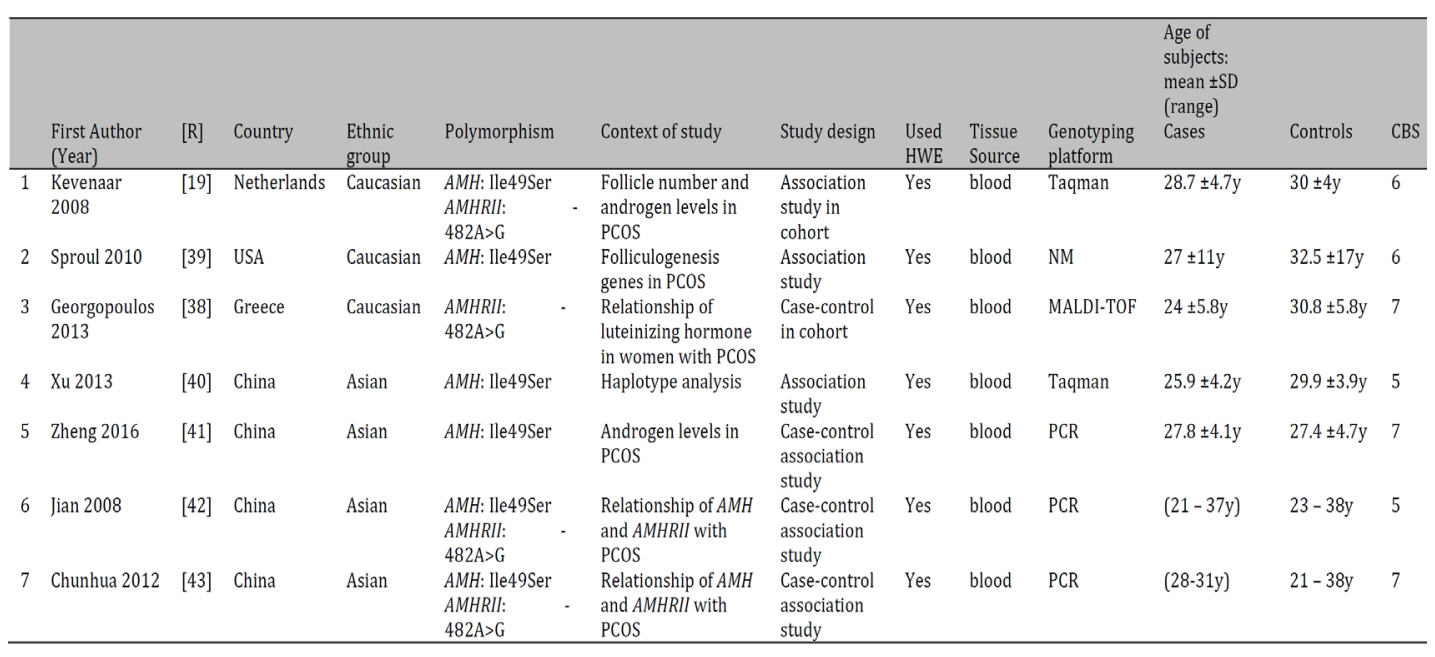

wise, the $-482 \mathrm{~A}>\mathrm{G}$ Caucasian effects in RO implied increased risk (OR 1.08-1.20, $\mathrm{P}=0.42$ $0.65)$.

\section{Heterogeneity analysis}

Effects of outlier treatment on the overall pooled ORs in both polymorphisms was generally erasure of heterogeneity (Tables 5 and 6). Figures 2 to 4 show effects of outlier treatment in the dominant model of Ile49Ser on heterogeneity. Figure 2 shows the preoutlier pooled OR with moderate heterogeneity $\left(\mathrm{P}=0.02, \mathrm{I}^{2}=58 \%\right)$ and Figure 4 shows the post-outlier effect resulting in zero heterogeneity $\left(\mathrm{P}=0.74, \mathrm{I}^{2}=0 \%\right)$. Zero heterogeneity $\left(\mathrm{I}^{2}\right.$ $=0 \%$ ) was also observed in the following comparisons: (i) Ile49Ser post-outlier pooled ORs in the codominant models of RO and homozygous/recessive models of PCOS. (ii) Caucasian 
Table 3. Genotype frequencies of $A M H$ and AMHRII polymorphisms with RO in women. RO: Reproductive Outcome; maf: minor allele frequency; HWE: Hardy-Weinberg Equilibrium

\begin{tabular}{|c|c|c|c|c|c|c|c|c|c|c|c|c|}
\hline & \multirow[b]{2}{*}{ First Author Year } & \multicolumn{3}{|c|}{ Sample sizes } & \multirow[b]{2}{*}{ wt-wt } & \multicolumn{2}{|l|}{ Cases } & \multirow[b]{2}{*}{ wt-wt } & \multicolumn{2}{|c|}{ Controls } & \multirow[b]{2}{*}{ maf } & \multirow[b]{2}{*}{ HWE } \\
\hline & & Case & Control & Total & & wt-var & var-var & & wt-var & var-var & & \\
\hline \multicolumn{13}{|c|}{$A M H$ Ile49Ser (rs10407022) } \\
\hline 1 & Chunhua 2012 [43] & 32 & 94 & 126 & 15 & 13 & 4 & 20 & 48 & 26 & 0.53 & 0.81 \\
\hline 2 & Hanevik 2010 [30] & 91 & 100 & 191 & 60 & 28 & 3 & 66 & 28 & 6 & 0.20 & 0.21 \\
\hline 3 & Karagiorgia 2015 [31] & 151 & 100 & 251 & 97 & 50 & 4 & 72 & 24 & 4 & 0.16 & 0.28 \\
\hline 4 & Qin 2014 [33] & 120 & 120 & 240 & 77 & 36 & 7 & 89 & 26 & 5 & 0.15 & 0.10 \\
\hline 5 & Rigon 2010 [16] & 76 & 100 & 176 & 64 & 12 & 0 & 70 & 30 & 0 & 0.15 & 0.08 \\
\hline 6 & Wang 2015 [35] & 62 & 60 & 122 & 26 & 24 & 12 & 26 & 30 & 4 & 0.32 & 0.23 \\
\hline 7 & Yoon 2013 [36] & 211 & 233 & 444 & 100 & 88 & 23 & 111 & 95 & 27 & 0.32 & 0.34 \\
\hline 8 & Yoshida 2014 [37] & 15 & 21 & 36 & 4 & 8 & 3 & 9 & 11 & 1 & 0.31 & 0.30 \\
\hline \multicolumn{13}{|c|}{ AMHRII $-482 \mathrm{~A}>\mathrm{G}(\mathrm{rs} 2002555)$} \\
\hline 1 & Chunhua 2012 [43] & 32 & 94 & 126 & 20 & 11 & 1 & 79 & 14 & 1 & 0.09 & 0.67 \\
\hline 2 & Hanevik 2010 [30] & 100 & 91 & 191 & 64 & 34 & 2 & 59 & 29 & 3 & 0.19 & 0.81 \\
\hline 3 & Karagiorgia $2015[31]$ & 148 & 100 & 248 & 103 & 43 & 2 & 68 & 30 & 2 & 0.17 & 0.53 \\
\hline 4 & Lazaros 2016 [32] & 300 & 300 & 600 & 224 & 69 & 7 & 233 & 63 & 4 & 0.12 & 0.91 \\
\hline 5 & Rigon $2010[16]$ & 76 & 100 & 176 & 56 & 18 & 2 & 63 & 31 & 6 & 0.22 & 0.41 \\
\hline 6 & Voorhuis 2010 [34] & 2,892 & 524 & 3,416 & 1,879 & 905 & 108 & 343 & 167 & 14 & 0.19 & 0.23 \\
\hline 7 & Yoon 2013 [36] & 211 & 233 & 444 & 131 & 73 & 7 & 142 & 85 & 6 & 0.21 & 0.10 \\
\hline 8 & Yoshida 2014 [37] & 17 & 23 & 40 & 12 & 2 & 3 & 11 & 9 & 3 & 0.33 & 0.60 \\
\hline
\end{tabular}

Table 4. Genotype frequencies of $A M H$ and AMHRII polymorphisms with PCOS. PCOS: Polycystic Ovary Syndrome; maf: minor allele frequency; HWE: Hardy-Weinberg Equilibrium

\begin{tabular}{|c|c|c|c|c|c|c|c|c|c|c|c|c|}
\hline & \multirow[b]{2}{*}{ First Author Year } & \multicolumn{3}{|c|}{ Sample sizes } & \multicolumn{3}{|c|}{ Cases } & \multicolumn{3}{|c|}{ Controls } & \multirow[b]{2}{*}{ maf } & \multirow[b]{2}{*}{ HWE } \\
\hline & & Case & Control & Total & wt-wt & wt-var & var-var & wt-wt & wt-var & var-var & & \\
\hline \multicolumn{13}{|c|}{ AMH Ile49Ser (rs10407022) } \\
\hline 1 & Chunhua 2012 [43] & 94 & 94 & 188 & 34 & 29 & 31 & 20 & 48 & 26 & 0.53 & 0.81 \\
\hline 2 & Jian 2008 [42] & 103 & 79 & 182 & 49 & 38 & 16 & 29 & 39 & 1 & 0.30 & 0.003 \\
\hline 3 & Kevenaar 2008 [18] & 331 & 32 & 363 & 208 & 110 & 13 & 24 & 8 & 0 & 0.13 & 0.42 \\
\hline 4 & Sproul 2010 [39] & 335 & 198 & 533 & 238 & 89 & 8 & 129 & 62 & 7 & 0.19 & 0.89 \\
\hline 5 & Xu 2013 [40] & 475 & 512 & 987 & 191 & 228 & 56 & 191 & 255 & 66 & 0.38 & 0.18 \\
\hline 6 & Zheng 2016 [41] & 94 & 94 & 188 & 20 & 48 & 26 & 34 & 29 & 31 & 0.48 & 0.0002 \\
\hline \multicolumn{13}{|c|}{ AMHRII -482A>G (rs2002555) } \\
\hline 1 & Chunhua 2012 [43] & 94 & 94 & 188 & 80 & 13 & 1 & 79 & 14 & 1 & 0.09 & 0.67 \\
\hline 2 & Georgopoulos 2013 [38] & 858 & 309 & 1,167 & 585 & 248 & 25 & 234 & 71 & 4 & 0.13 & 0.59 \\
\hline 3 & Jian 2008 [42] & 103 & 79 & 182 & 55 & 41 & 7 & 52 & 22 & 5 & 0.20 & 0.22 \\
\hline 4 & Kevenaar 2008 [18] & 331 & 32 & 363 & 224 & 94 & 13 & 20 & 12 & 0 & 0.19 & 0.19 \\
\hline
\end{tabular}

Ile49Ser effects in R0; and (iii) all homozygous and recessive effects (overall and subgroups) in $-482 \mathrm{~A}>\mathrm{G}$ of both polymorphisms (Tables 5 and 6 ).

\section{Sensitivity analysis}

Table 7 summarizes the changes in association resulting from sensitivity treatment. These changes affected all comparisons in every genetic model. Of the four comparisons, Ile49Ser in RO was least robust as the pooled ORs were altered with omission of a total of five studies $[16,30,31,36,43]$ in every genetic model. By contrast, $-482 \mathrm{~A}>\mathrm{G}$ was non-robust in the dominant model only, attributed to two studies $[32,43]$. In terms of genetic model, pooled ORs in the homozygous and recessive models were deemed robust in $-482 \mathrm{~A}>\mathrm{G}$ comparisons.

\section{Discussion}

With a sample size of 9,210 for both polymorphisms in RO and PCOS, our meta-analysis has shown that genotypes in the $A M H$ and $A M H R I$ genes are not significantly associated with RO and PCOS. Despite the non-significance, subgroup analysis delineated pooled effects between the ethnic groups and outlier treatment erased heterogeneity, which thus rendered greater confidence in the post-outlier results. However, another consequence of outlier treatment was change in direction of association such that the original close to null pooled ORs became 1.2-fold increased risk in Ile49Ser and 1.2-fold increased risk became 


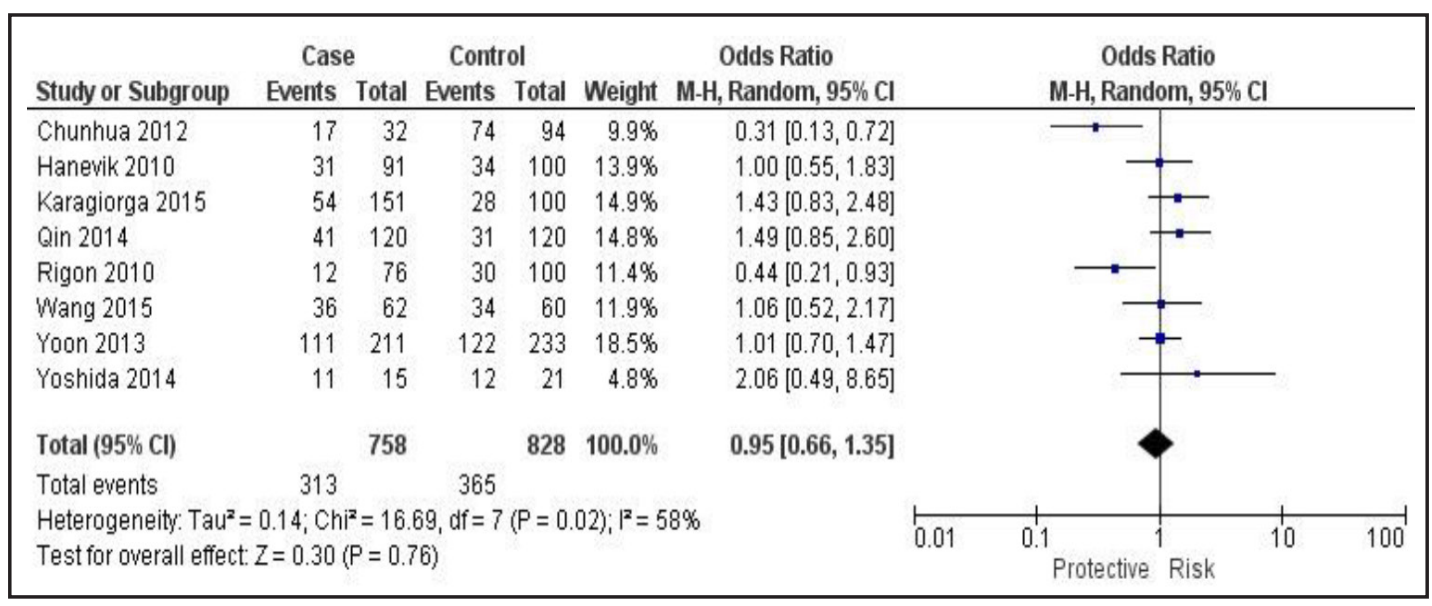

Fig. 2. Forest plot showing the dominant influence of the Ile49Ser polymorphism on RO outcomes in women. Black diamond denotes the pooled OR. Blue squares indicate the OR in each study, with square sizes directly proportional to the weight contribution (\%) of the study. Horizontal lines represent 95\% confidence intervals. RO: Reproductive Outcomes; OR: Odds Ratio; M-H: Mantel-Haenszel; CI: confidence interval; df: degree of freedom

Fig. 3. Galbraith plot analysis to detect sources of heterogeneity in the dominant model. OR: Odds Ratio; SE: Standard Error.

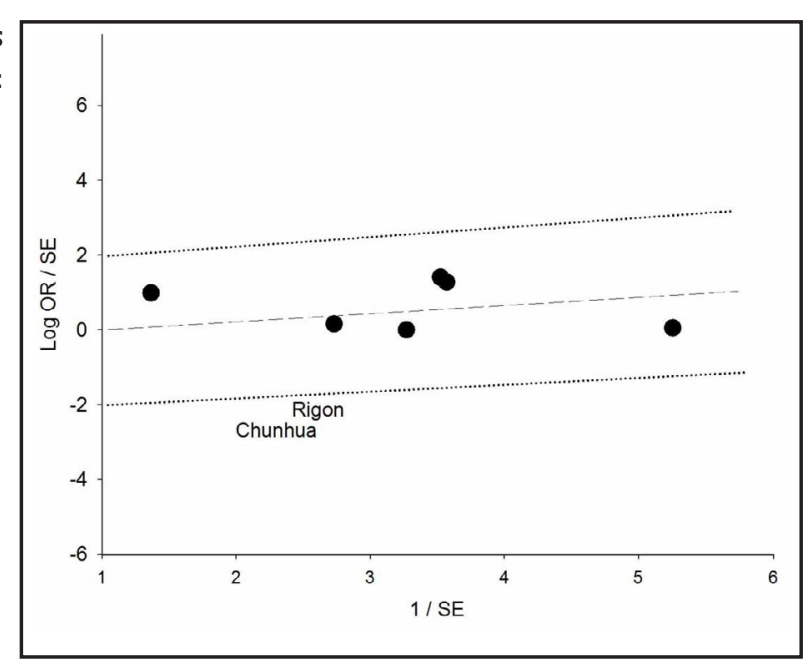

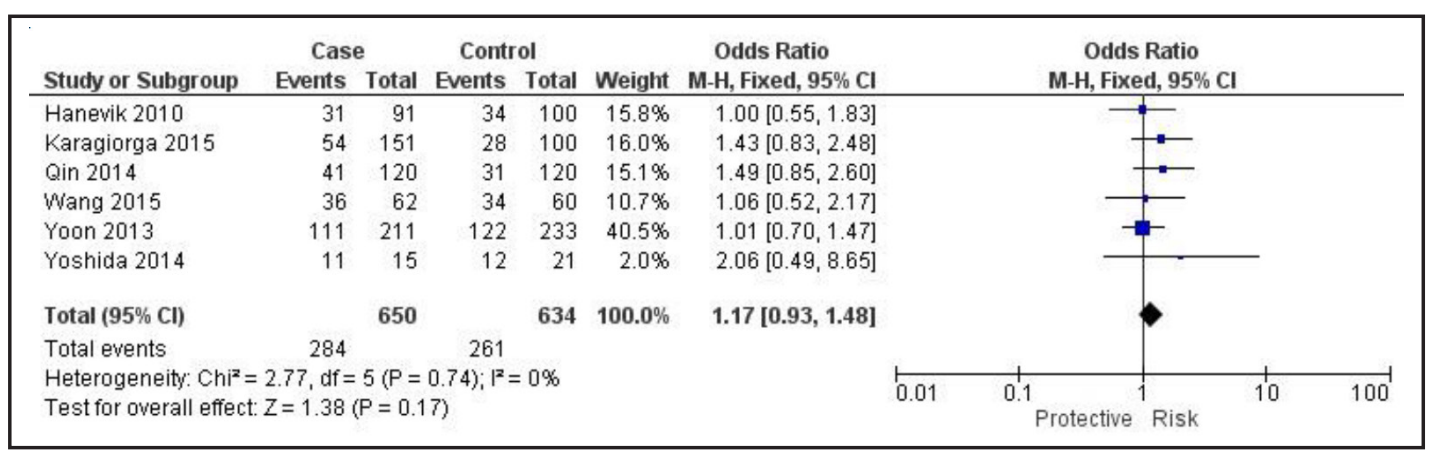

Fig. 4. Forest plot showing the dominant post-outlier influence of the Ile49Ser polymorphism on RO in women. Black diamond denotes the pooled OR. Blue squares indicate the OR in each study, with square sizes directly proportional to the weight contribution (\%) of the study. Horizontal lines represent $95 \%$ confidence intervals. RO: Reproductive Outcomes; OR: Odds Ratio; M-H: Mantel-Haenszel; CI: confidence interval; df: degree of freedom

protective for up to $10 \%$ in $-482 \mathrm{~A}>\mathrm{G}$. Despite the clinical heterogeneity of R0, post-outlier values were statistically non-heterogeneous, zero in the dominant and codominant models. 
Table 5. Summary associations of the $A M H$ Ile49Ser and $A M$ HRII $-482 \mathrm{~A}>\mathrm{G}$ polymorphisms with RO outcomes in women. RO: Reproductive Outcomes; $\mathrm{N}$ : number of studies; OR: Odds Ratio; CI: Confidence Interval; $P^{a}$ : $\mathrm{P}$ value for association with significance set at $<0.05 ; P^{b}$ : $\mathrm{P}$ value for heterogeneity with significance set at <0.10; $\mathrm{I}^{2}$ values as measure of heterogeneity are considered low (<44\%), moderate $(45-74 \%)$ or high $(>75 \%)$; R: Random-effects; F: Fixed-effects

\begin{tabular}{|c|c|c|c|c|c|c|c|}
\hline \multirow[b]{2}{*}{$A M H$ Ile49Ser } & \multirow[b]{2}{*}{$\mathrm{N}$} & \multicolumn{3}{|c|}{ Test of association } & \multicolumn{3}{|c|}{ Test of heterogeneity } \\
\hline & & OR & $95 \% \mathrm{CI}$ & $P^{a}$ & $P^{\mathrm{b}}$ & $I^{2}(\%)$ & $\begin{array}{c}\text { Analysis } \\
\text { Model }\end{array}$ \\
\hline \multicolumn{8}{|l|}{ Overall } \\
\hline Homozygous & 8 & 0.98 & $0.52-1.85$ & 0.96 & 0.08 & 45 & $\mathrm{R}$ \\
\hline Recessive & 8 & 0.99 & $0.68-1.45$ & 0.98 & 0.18 & 31 & $\mathrm{~F}$ \\
\hline Dominant & 8 & 0.95 & $0.66-1.35$ & 0.76 & 0.02 & 58 & $\mathrm{R}$ \\
\hline Codominant & 8 & 0.99 & $0.73-1.33$ & 0.94 & 0.01 & 62 & $\mathrm{R}$ \\
\hline \multicolumn{8}{|l|}{ Post-outlier } \\
\hline Homozygous & 7 & 1.18 & $0.77-1.80$ & 0.45 & 0.40 & 3 & $\mathrm{~F}$ \\
\hline Recessive & 7 & 1.16 & $0.77-1.75$ & 0.47 & 0.33 & 14 & $\mathrm{~F}$ \\
\hline Dominant & 6 & 1.17 & $0.93-1.48$ & 0.17 & 0.74 & 0 & $\mathrm{~F}$ \\
\hline $\begin{array}{l}\text { Codominant } \\
\text { Asian }\end{array}$ & 6 & 1.15 & $0.96-1.38$ & 0.13 & 0.46 & 0 & $\mathrm{~F}$ \\
\hline Homozygous & 5 & 1.18 & $0.47-2.97$ & 0.73 & 0.02 & 66 & $\mathrm{R}$ \\
\hline Recessive & 5 & 1.24 & $0.58-2.63$ & 0.58 & 0.07 & 55 & $\mathrm{R}$ \\
\hline Dominant & 5 & 0.97 & $0.60-1.59$ & 0.91 & 0.03 & 61 & $\mathrm{R}$ \\
\hline \multicolumn{8}{|l|}{ Caucasian } \\
\hline Homozygous & 3 & 0.68 & $0.26-1.73$ & 0.42 & 0.90 & 0 & $\mathrm{~F}$ \\
\hline Recessive & 3 & 0.64 & $0.25-1.64$ & 0.36 & 0.85 & 0 & $\mathrm{~F}$ \\
\hline Dominant & 3 & 0.89 & $0.47-1.70$ & 0.73 & 0.04 & 68 & $\mathrm{R}$ \\
\hline Codominant & 3 & 0.87 & $0.53-1.43$ & 0.58 & 0.09 & 58 & $\mathrm{R}$ \\
\hline \multicolumn{8}{|c|}{ AMHRII $-482 \mathrm{~A}>\mathrm{G}$} \\
\hline \multicolumn{8}{|c|}{ Overall } \\
\hline Homozygous & 8 & 1.21 & $0.81-1.80$ & 0.35 & 0.74 & 0 & $\mathrm{~F}$ \\
\hline Recessive & 8 & 1.24 & $0.84-1.85$ & 0.28 & 0.82 & 0 & $\mathrm{~F}$ \\
\hline Dominant & 8 & 1.02 & $0.88-1.17$ & 0.82 & 0.12 & 38 & $\mathrm{~F}$ \\
\hline \multicolumn{8}{|l|}{ Asian } \\
\hline Homozygous & 3 & 1.29 & $0.52-3.16$ & 0.58 & 0.69 & 0 & $\mathrm{~F}$ \\
\hline Recessive & 3 & 1.44 & $0.59-3.48$ & 0.42 & 0.86 & 0 & $\mathrm{~F}$ \\
\hline Dominant & 3 & 0.88 & $0.44-1.77$ & 0.72 & 0.01 & 77 & $\mathrm{R}$ \\
\hline Codominant & 3 & 0.88 & $0.44-1.77$ & 0.72 & 0.01 & 77 & $\mathrm{R}$ \\
\hline \multicolumn{8}{|l|}{ Caucasian } \\
\hline Homozygous & 5 & 1.19 & $0.76-1.86$ & 0.44 & 0.47 & 0 & $\mathrm{~F}$ \\
\hline Recessive & 5 & 1.20 & $0.77-1.87$ & 0.42 & 0.53 & 0 & $\mathrm{~F}$ \\
\hline Dominant & 5 & 1.08 & $0.77-1.51$ & 0.65 & 0.09 & 51 & $\mathrm{R}$ \\
\hline Codominant & 5 & 1.08 & $0.77-1.51$ & 0.65 & 0.09 & 51 & $\mathrm{R}$ \\
\hline
\end{tabular}

To our knowledge, this is the first meta-analysis to address $A M H$ associations in both RO and PCOS. Study specific findings of RO and PCOS were variable, with contradictions among the results. Absence of associations between the $A M H$ and AMHRII polymorphisms and ovarian stimulation have been reported [30,35] and contradicted in another study [31]. Regarding ovarian insufficiency, findings of no association [36] were countered by other studies that found associations $[33,43]$. Associations of Ile49Ser and $-482 \mathrm{~A}>\mathrm{G}$ with PCOS have been reported [38, 41, 43] but found absent in other studies [19, 39, 40, 42]. These findings indicate lack of consistency in the outcome of these association studies. Here, then enters the utility of our meta-analysis.

AMH levels are currently used in clinical practice to predict response to stimulation [6], its value is recognized in a range of clinical settings, from PCOS to ovarian assessment following cancer treatment [45]. PCOS has been found to cause significantly increased risk of ovarian hyperstimulation syndrome [46]. In addition, impact of AMH receptor polymorphism have been studied in other diseases such as breast cancer [47] and cryptorchidism [48].

Hence, reproductive studies in women have focused on the role of serum AMH as marker for ovarian response and reserve [31]. AMH has the advantage of having relatively stable levels throughout the menstrual cycle $[49,50]$ and is more accurate in providing information on the expected ovarian response to controlled stimulation [50]. However, AMH is limited in extreme responses as it is not reliably predictive in this situation, and also its value has been questioned [51]. Nevertheless, considering the important role of the AMH signaling pathway in regulating sensitivity in the ovary and follicular recruitment, it is appropriate to consider that variation in the genes encoding key proteins in the pathway may influence ovarian response. Genetic variation in $A M H$ studies demonstrated that Ile49Ser and $-482 \mathrm{~A}>\mathrm{G}$ were associated with an increase in estradiol (E2) and AMH levels during the follicular phase of 
Pabalan et al.: AMH and AMHRII Genes, Reproductive Outcomes and Polycystic Ovary Syndrome

Table 6. Summary associations of the AMH Ile49Ser and AMHRII -482A>G polymorphisms with PCOS. PCOS: Polycystic Ovary Syndrome; HWE: Hardy-Weinberg Equilibrium; N: number of studies; OR: Odds Ratio; CI: Confidence Interval; $P^{a}$ : p value for association with significance set at $<0.05 ; P^{b}$ : $\mathrm{p}$ value for heterogeneity with significance set at $<0.10$; $\mathrm{I}^{2}$ values as measure of heterogeneity are considered low $(<44 \%)$, moderate (45$74 \%$ ) or high (>75\%); R: Random-effects; F: Fixed-effects

\begin{tabular}{lccccccc}
\hline & \multicolumn{6}{c}{ Test of association } & \multicolumn{3}{c}{ Test of heterogeneity } \\
AMH Ile49Ser & $\mathrm{N}$ & OR & $95 \% \mathrm{CI}$ & $P^{\mathrm{a}}$ & $P^{\mathrm{b}}$ & $I^{2}(\%)$ & Analysis \\
Model
\end{tabular}

Table 7. Summary of sensitivity analysis findings. Entries with references imply non-robustness of the summary effects; * least robust based on absence of robust comparisons; ** most robust as it had the most number of robust comparisons; RO: Reproductive outcomes; AMH: Anti-Müllerian Hormone; AMHRII: Anti-Müllerian Hormone Receptor II; PCOS: Polycystic Ovary Syndrome

\begin{tabular}{|c|c|c|c|c|}
\hline \multirow[b]{2}{*}{ Genetic Model } & \multicolumn{4}{|c|}{ Outcome Polymorphism } \\
\hline & RO Ile49Ser & $\mathrm{RO}-482 \mathrm{~A}>\mathrm{G}$ & PCOS Ile49Ser & $\mathrm{PCOS}-482 \mathrm{~A}>\mathrm{G}$ \\
\hline Homozygous & {$[30,31,36,43]$} & Robust & {$[42]$} & Robust \\
\hline Recessive & {$[30,31,36,43]$} & Robust & [42] & Robust \\
\hline Dominant & {$[16,43]$} & {$[32,43]$} & Robust & [42] \\
\hline Codominant & {$[16,30,43]$} & Robust & [38] & [42] \\
\hline Number of references that contributed to instability & 5 & 2 & 2 & 1 \\
\hline Number of robust comparisons & 0 * & $3 * *$ & 1 & 2 \\
\hline
\end{tabular}

the menstrual cycle in healthy normo-ovulatory women [15] as well as with the number of embryos produced [52]. Significant differences between certain subgroups were found following controlled ovarian stimulation amongst women with wild type for the $A M H$ polymorphism [31]. In addition, women with wild-type for the AMHRII polymorphism had a higher number of follicles, and those with higher peak serum E2 levels required a lower gonadotropin dose [31]. These polymorphisms have been demonstrated to be of predictive utility in ovarian stimulation procedures (reviewed in [53]).

Interpreting the results of this meta-analysis warrant awareness of its strengths and limitations. Strengths include the following: (i) all tissue sources were blood; (ii) all of the studies addressed the HWE issues; (iii) efficiency of outlier treatment in erasing heterogeneity and altering direction of association enabling the findings to be without the baggage of variability; (iii) zero heterogeneity in most comparisons of the $-482 \mathrm{~A}>\mathrm{G}$ polymorphism. (iv) Pooled ORs of $-482 \mathrm{~A}>\mathrm{G}$ in RO and PCOS were robust in the homozygous and recessive models. On the other hand, there are a number of limitations in our study: (i) 
low statistical power of most included studies. Of the 16 studies, only five (31\%) had sample sizes of $>500[32,34,38-40]$. (ii) The $-482 \mathrm{~A}>\mathrm{G}$ comparisons had a small number of studies thus with limited statistical power; (iii) since we included studies whose controls deviated from the HWE, we risked methodological weakness, such as biased selection of subjects, genotyping errors and population stratification [54]. However, non-significance remained with omission of these studies followed by recalculation. (iv) Genotyping approaches were not uniform although most of the studies used PCR (Polymerase Chain Reaction). (v) Pooled ORs in Ile49Ser were generally not robust.

\section{Conclusion}

It is possible that Ile49Ser and $-482 \mathrm{~A}>\mathrm{G}$ do not play any direct functional role in RO and PCOS, but are in linkage disequilibrium (LD) with other polymorphisms [19]. It is also likely that variants in other than $A M H$ or $A M H R I I$ are relevant to RO and PCOS [15, 31, 32, 40]. It is possible that the Ile49Ser and $-482 \mathrm{~A}>\mathrm{G}$ polymorphisms are merely markers for the truly functional polymorphism elsewhere in these genes [15]. Lazaros et al [32] suggested a concerted effect between $-482 \mathrm{~A}>\mathrm{G}$ and $1749 \mathrm{C} 4 \mathrm{~T}$, since both polymorphisms in AMHRII were found to be in strong LD. Genome wide association studies may be promising as did a recent one that found significant correlation with ovarian response [55]. It is conceivable that RO and PCOS related to any one locus will be small because gene-gene as well as gene-environment interactions are likely to operate. Genotyping the $A M H$ and $A M H R I I$ polymorphisms together with some additional markers may provide a means of identifying RO. Meanwhile, further studies regarding other SNPs (or haplotypes) in the $A M H$ and AMHRII genes may help better understand their roles in RO/PCOS. Since potential biases and confounders could not be ruled out completely in this meta-analysis, additional large case-control studies or later update meta-analysis may be warranted to validate or modify our findings. It would help that well-designed studies based on sample sizes commensurate with detection of small genotypic risks should allow more definitive conclusions about the association of $A M H$ and AMHRII polymorphisms and RO/PCOS.

\section{Acknowledgements}

This work was supported by FAPESP research grants \#2014/06177-2.

\section{Disclosure Statement}

The authors have nothing to disclose and no conflicts of interest to declare.

\section{References}

1 Burns T: Infertility Part I: Pathophysiology and diagnosis. Ariz Med 1977;34:170-172.

2 Skakkebaek NE, Jørgensen N, Main KM, Rajpert-De Meyts E, Leffers H, Andersson AM, Juul A, Carlsen E, Mortensen GK, Jensen TK, Toppari J: Is human fecundity declining? Int J Androl 2006;29:2-11.

3 Cate RL, Mattaliano RJ, Hession C, Tizard R, Farber NM, Cheung A, Ninfa EG, Frey AZ, Gash DJ, Chow EP, et al: Isolation of the bovine and human genes for Müllerian inhibiting substance and expression of the human gene in animal cells. Cell 1986;45:685-698.

4 Ueno S, Kuroda T, Maclaughlin DT, Ragin RC, Manganaro TF, Donahoe PK: Mullerian inhibiting substance in the adult rat ovary during various stages of the estrous cycle. Endocrinology 1989;125:1060-1066. 
5 Vigier B, Picard JY, Tran D, Legeai L, Josso N: Production of anti-Müllerian hormone: another homology between Sertoli and granulosa cells. Endocrinology 1984;114:1315-1320.

6 Visser JA, de Jong FH, Laven JS, Themmen AP: Anti-Müllerian hormone: a new marker for ovarian function. Reproduction 2006;131:1-9.

7 van Rooij IA, Broekmans FJ, Scheffer GJ, Looman CW, Habbema JD, de Jong FH, Fauser BJ, Themmen AP, te Velde ER: Serum antimullerian hormone levels best reflect the reproductive decline with age in normal women with proven fertility: a longitudinal study. Fertil Steril 2005;83:979-987.

8 di Clemente N, Josso N, Gouédard L, Belville C: Components of the anti-Müllerian hormone signaling pathway in gonads. Mol Cell Endocrinol 2003;211:9-14.

9 Visser JA, Themmen AP: Anti-Müllerian hormone and folliculogenesis. Mol Cell Endocrinol 2005;234:8186.

10 Broer SL, Dólleman M, Opmeer BC, Fauser BC, Mol BW, Broekmans FJ: AMH and AFC as predictors of excessive response in controlled ovarian hyperstimulation: a meta-analysis. Hum Reprod Update 2011;17:46-54.

11 Rey R, Lukas-Croisier C, Lasala C, Bedecarrás P: AMH/MIS: what we know already about the gene, the protein and its regulation. Mol Cell Endocrinol 2003;211:21-31.

12 Weenen C, Laven JS, Von Bergh AR, Cranfield M, Groome NP, Visser JA, Kramer P, Fauser BC, Themmen AP: Anti-Müllerian hormone expression pattern in the human ovary: potential implications for initial and cyclic follicle recruitment. Mol Hum Reprod 2004;10:77-83.

13 Wilson CA, di Clemente N, Ehrenfels C, Pepinsky RB, Josso N, Vigier B, Cate RL: Mullerian inhibiting substance requires its $\mathrm{N}$-terminal domain for maintenance of biological activity, a novel finding within the transforming growth factor-beta superfamily. Mol Endocrinol 1993;7:247-257.

14 La Marca A, Volpe A. Anti-Müllerian hormone (AMH) in female reproduction: is measurement of circulating AMH a useful tool? Clin Endocrinol (Oxf) 2006;64:603-610.

15 Kevenaar ME, Themmen AP, Laven JS, Sonntag B, Fong SL, Uitterlinden AG, de Jong FH, Pols HA, Simoni M, Visser JA: Anti-Müllerian hormone and anti-Müllerian hormone type II receptor polymorphisms are associated with follicular phase estradiol levels in normo-ovulatory women. Hum Reprod 2007;22:15471554.

16 Rigon C, Andrisani A, Forzan M, D'Antona D, Bruson A, Cosmi E, Ambrosini G, Tiboni GM, Clementi M: Association study of AMH and AMHRII polymorphisms with unexplained infertility. Fertil Steril 2010;94:1244-1248.

17 Schuh-Huerta SM, Johnson NA, Rosen MP, Sternfeld B, Cedars MI, Reijo Pera RA: Genetic variants and environmental factors associated with hormonal markers of ovarian reserve in Caucasian and African American women. Hum Reprod 2012;27:594-608.

18 Kevenaar ME, Themmen AP, Rivadeneira F, Uitterlinden AG, Laven JS, van Schoor NM, Lips P, Pols HA, Visser JA: A polymorphism in the AMH type II receptor gene is associated with age at menopause in interaction with parity. Hum Reprod 2007;22:2382-2388.

19 Kevenaar ME, Laven JS, Fong SL, Uitterlinden AG, de Jong FH, Themmen AP, Visser JA: A functional anti-mullerian hormone gene polymorphism is associated with follicle number and androgen levels in polycystic ovary syndrome patients. J Clin Endocrinol Metab 2008;93:1310-1316.

20 Palioura E, Palimeri S, Piperi C, Sakellariou S, Kandaraki E, Sergentanis T, Levidou G, Agrogiannis G, Papalois A, Korkolopoulou P, Diamanti-Kandarakis E, Papavassiliou AG: Impact of androgen and dietary advanced glycation end products on female rat liver. Cell Physiol Biochem 2015;37:1134-1146.

21 Long W, Zhao C, Ji C, Ding H, Cui Y, Guo X, Shen R, Liu J: Characterization of serum microRNAs profile of PCOS and identification of novel non-invasive biomarkers. Cell Physiol Biochem 2014;33:1304-1315.

22 Clark MF, Baudouin SV: A systematic review of the quality of genetic association studies in human sepsis. Intensive Care Med 2006;32:1706-1712.

23 Mantel N, Haenszel W: Statistical aspects of the analysis of data from retrospective studies of disease. J Natl Cancer Inst 1959;22:719-748.

24 DerSimonian R, Laird N: Meta-analysis in clinical trials. Control Clin Trials 1986;7:177-188.

25 Lau J, Ioannidis JP, Schmid CH: Quantitative synthesis in systematic reviews. Ann Intern Med 1997;127:820-826.

26 Higgins JP, Thompson SG, Deeks JJ, Altman DG: Measuring inconsistency in meta-analyses. BMJ 2003;327:557-560. 
27 Higgins JP, Thompson SG: Quantifying heterogeneity in a meta-analysis. Stat Med 2002;21:1539-1558.

28 Ioannidis JP, Trikalinos TA: The appropriateness of asymmetry tests for publication bias in meta-analyses: a large survey. CMAJ 2007;176:1091-1096.

29 Moher D, Liberati A, Tetzlaff J, Altman DG; PRISMA Group: Preferred reporting items for systematic reviews and meta-analyses: the PRISMA statement. PLoS Med 2009;6:e1000097.

30 Hanevik HI, Hilmarsen HT, Skjelbred CF, Tanbo T, Kahn JA: Single nucleotide polymorphisms in the antiMüllerian hormone signalling pathway do not determine high or low response to ovarian stimulation. Reprod Biomed Online 2010;21:616-623.

31 Karagiorga I, Partsinevelos GA, Mavrogianni D, Anagnostou E, Zervomanolakis I, Kallianidis K, Drakakis P, Loutradis D: Single nucleotide polymorphisms in the Anti-Müllerian hormone (AMH Ile(49)Ser) and Anti-Müllerian hormone type II receptor (AMHRII -482 A>G) as genetic markers in assisted reproduction technology. J Assist Reprod Genet 2015;32:357-367.

32 Lazaros L, Fotaki A, Pamporaki C, Hatzi E, Kitsou C, Zikopoulos A, Virgiliou C, Kosmas I, Bouba I, Stefos T, Theodoridis G, Georgiou I: The ovarian response to standard gonadotropin stimulation is influenced by AMHRII genotypes. Gynecol Endocrinol 2016. [Epub ahead of print].

33 Qin C, Yuan Z, Yao J, Zhu W, Wu W, Xie J: AMH and AMHR2 genetic variants in Chinese women with primary ovarian insufficiency and normal age at natural menopause. Reprod Biomed Online 2014;29:311-318.

34 Voorhuis M, Broekmans FJ, Fauser BC, Onland-Moret NC, van der Schouw YT: Genes involved in initial follicle recruitment may be associated with age at menopause. J Clin Endocrinol Metab 2011;96:E473-E479.

35 Wang L, Li H, Ai J, Zhang H, Zhao Y: Possible involvement of single nucleotide polymorphisms in antiMüllerian hormone signaling pathway in the pathogenesis of early OHSS in Han Chinese women. Int J Clin Exp Pathol 2015;8:9552-9559.

36 Yoon SH, Choi YM, Hong MA, Kim JJ, Lee GH, Hwang KR, Moon SY: Association study of anti-Mullerian hormone and anti-Mullerian hormone type II receptor polymorphisms with idiopathic primary ovarian insufficiency. Hum Reprod 2013;28:3301-3305.

37 Yoshida Y, Yamashita Y, Saito N, Ono Y, Yamamoto H, Nakamura Y, Hayashi A, Terai Y, Ohmichi M: Analyzing the possible involvement of anti-Müllerian hormone and anti-Müllerian hormone receptor II single nucleotide polymorphism in infertility. J Assist Reprod Genet 2014;31:163-168.

38 Georgopoulos NA, Karagiannidou E, Koika V, Roupas ND, Armeni A, Marioli D, Papadakis E, Welt CK, Panidis D: Increased frequency of the anti-mullerian-inhibiting hormone receptor 2 (AMHR2) $482 \mathrm{~A}>\mathrm{G}$ polymorphism in women with polycystic ovary syndrome: relationship to luteinizing hormone levels. J Clin Endocrinol Metab;98:E1866-E1870.

39 Sproul K, Jones MR, Mathur R, Azziz R, Goodarzi MO: Association study of four key folliculogenesis genes in polycystic ovary syndrome. BJOG 2010;117:756-760.

40 Xu P, Shen SM, Zhang XL, Liang F, Xie GB, Yi L, Gao Q, Wang Y: Haplotype analysis of single nucleotide polymorphisms in anti-Müllerian hormone gene in Chinese PCOS women. Arch Gynecol Obstet 2013;288:125-130.

41 Zheng MX, Li Y, Hu R, Wang FM, Zhang XM, Guan B: Anti-Müllerian hormone gene polymorphism is associated with androgen levels in Chinese polycystic ovary syndrome patients with insulin resistance. J Assist Reprod Genet 2016;33:199-205.

42 Jian L, Jie Q, Liying Y: Relationship between polymorphism of anti-mullerian hormone, anit-mullerian hormone receptor type II and polycystic ovary syndrome. Chin J Clin Obstet Gynecol 2008;9:206-210.

43 Chunhua T, Rong H, Shaotong J: Association between Gene Polymorphisms of Anti-Mullerian Hormone and its Type II Receptor and Ovarian Reserve. Acta Med Univ Sci Technol Hauzhong 2012;41:315.

44 Berthold VMR, Borgelt C, Höppner F, Klawonn F: How to Intelligently Make Sense of Real Data, in Descriptive Statistics. Guide to Intelligent Data Analysis, Springer, 2010, p 315.

45 Nelson SM, Yates RW, Lyall H, Jamieson M, Traynor I, Gaudoin M, Mitchell P, Ambrose P, Fleming R: AntiMüllerian hormone-based approach to controlled ovarian stimulation for assisted conception. Hum Reprod 2009;24:867-875.

46 Zhao C, Liu X, Shi Z, Zhang J, Zhang J, Jia X, Ling X: Role of serum miRNAs in the prediction of ovarian hyperstimulation syndrome in polycystic ovarian syndrome patients. Cell Physiol Biochem 2015;35:10861094. 


\section{Cellular Physiology Cell Physiol Biochem 2016;39:2249-2261}

\begin{tabular}{ll|l} 
and Biochemistry & $\begin{array}{l}\text { DOI 10.1159/000447918 } \\
\text { Published online: November 07, } 2016\end{array}$ & $\begin{array}{l}\text { O 2016 The Author(s). Published by S. Karger AG, Basel } \\
\text { www.karger.com/cpb }\end{array}$ \\
\cline { 2 - 3 }
\end{tabular}

Pabalan et al.: AMH and AMHRII Genes, Reproductive Outcomes and Polycystic Ovary Syndrome

47 Nan H, Dorgan JF, Rebbeck TR: Genetic variants in anti-Mullerian hormone and anti-Mullerian hormone receptor genes and breast cancer risk in Caucasians and African Americans. Int J Mol Epidemiol Genet 2014;5:145-151.

48 Komarowska MD, Milewski R, Charkiewicz R, Matuszczak E, Sulewska A, Zelazowska-Rutkowska B, Hermanowicz J, Niklinski J, Debek W, Hermanowicz A: Are anti-Müllerian hormone and its receptor polymorphism associated with the hormonal condition of undescended testes? Adv Med Sci 2016;61:288292.

49 Elgindy EA, El-Haieg DO, El-Sebaey A: Anti-Müllerian hormone: correlation of early follicular, ovulatory and midluteal levels with ovarian response and cycle outcome in intracytoplasmic sperm injection patients. Fertil Steril 2008;89:1670-1676.

50 La Marca A, Stabile G, Artenisio AC, Volpe A: Serum anti-Mullerian hormone throughout the human menstrual cycle. Hum Reprod 2006;21:3103-3107.

51 Rustamov O, Smith A, Roberts SA, Yates AP, Fitzgerald C, Krishnan M, Nardo LG, Pemberton PW: The measurement of anti-Müllerian hormone: a critical appraisal. J Clin Endocrinol Metab 2014;99:723-732.

52 Peluso C, Fonseca FL, Gastaldo GG, Christofolini DM, Cordts EB, Barbosa CP, Bianco B: AMH and AMHR2 polymorphisms and AMH serum level can predict assisted reproduction outcomes: a cross-sectional study. Cell Physiol Biochem 2015;35:1401-1412.

53 Peluso C, Fonseca FL, Rodart IF, Cavalcanti V, Gastaldo G, Christofolini DM, Barbosa CP, Bianco B: AMH: An ovarian reserve biomarker in assisted reproduction. Clin Chim Acta 2014;437:175-182.

54 Thakkinstian A, McElduff P, D'Este C, Duffy D, Attia J: A method for meta-analysis of molecular association studies. Stat Med 2005;24:1291-1306.

55 Braem MG, Voorhuis M, van der Schouw YT, Peeters PH, Schouten LJ, Eijkemans MJ, Broekmans FJ, Onland-Moret NC: Interactions between genetic variants in AMH and AMHR2 may modify age at natural menopause. PLoS One 2013;8:e59819. 